\title{
DOES THE WRITER OF ENGLISH TEXTBOOK INTEGRATE NORMS IN READING PASSAGES HE/SHE WROTE?
}

\author{
Achmad Hilal Madjdi and Atik Rokhayani \\ UniversitasMuria Kudus, Indonesia
}

\begin{abstract}
A serious challenge which is faced by teachers is educating character and bringing norms being practiced by the society into the classrooom, and English teacher is no exception. The challenge makes IndonesianEducation is very dynamic as everything dealing with normsis always thethe concern and developed by scholars, parents as well as the government. Some scholars propose to foster English teachers as models of practicing norms, while some others think to integrate norms into teaching materials. The second thought invites curriousity on how the writer of English textbook supports the recent concern on norms, and the research on it becomes very important to do. Therefore the research dealing with several reading passages in the English Textbook was done. The design was descriptive qualitative which aimed at investigating whether the writer of English textbook integrates norms in reading passages he/ she wrote. The data was norms, while the data sources were reading passages in the 2015-English Textbook developed by The Ministry of Education and Culture. The result describes that norms of trust, discipline, respect to others and self-confidence were found in reading passages. It can be then concluded that the writer of English textbook integratesnorms in the text he/ she writes. The results of the research implies not only the seriousness of scholars, parents and government in fostering character education, but also the support and care of textbook writer in succeeding the education.It is therefore suggested to teachers, scholars as well as book writer to always concern with the society's need in developing education, especially in sharing the existed and practiced norms.
\end{abstract}

Key words: norms,readingpassages, character education.

\section{INTRODUCTION}

A great change has appeared in English teaching in Indonesia since it is managed under the framework of both 2013 Curriculum and KTSP Curriculum. The interesting thing is that, the 2013 Curriculum points the importance of students' mastery not only on the knowledge and skills, but also on attitude/ norms.In other words, English language learning aims to improve language skills and attitude. In 2013 Curriculum, English language skills are taught through sustainable learning by improving the competence of knowledge about the types, principles and context of a text, followed by competency skills presented in written and spoken text either planned or spontaneous.

It has been very common that school curriculum is always developed from time to time due to the development of the society and technology. In Indonesia, after political and governmental reform, the Ministry of Education and Culture designed and implemented Competency Based Curriculum (CBC) for all schools. Some ten years later, the CBC developed into Education Institution Based Curriculum (EIBC). Nowadays, however, the policy has been changed so that 
some schools apply the so called "2013 curriculum" but some others still use the former one (EIBC).

The English teacher challenges dealing with the use of two curriculums are not of that simple. However, they should be treated as projects to innovate English learning environment in such a way that the actual language used is the concern of both the teacher and students in an integral part of the interactions themselves (Harmer, 2007). For $\mathrm{Wu}$ and $\mathrm{Wu}$ (2008), Harmer's opinion is interpreted as how to maximize language exposure and to simulate social interaction. On the other hand, in any social interaction of whatever its cultural background, according toKertajaya (2011), there will always be ethical interaction which shares six pillars of character or norm.

Therefore, comprehending text should be followed by performing good pronunciation and appropriate intonation and lead to the formation of the attitude of politeness and respect for the language users. In such high targeted learning goals, English textbooksthen play an important role in the teaching and learning process. Usually, English teachers use one textbook as the primary source of teaching. It is, of course, not a good thing since the materials of teaching does not only come from the textbook. The materials can be from the other resources, internet, English newspapers, books, etc.

In fact, Indonesian government has prepared the textbook which is written on the basis of the 2013 curriculum. Therefore, it becomes interesting for the researchers to find out if the "government textbook" has seriously prepared to develop the demand of facilitating students'mastery on knowledge and language skills as well as characters or norms. Specifically, the researchers want to investigate if there are characters or norms being shared through the reading passages in the "government" English textbook.

Norms orAttitude are always discussed in the framework of building human character or morality which is always presumed as a matter of how a person builds transactions with his/ her communities. In this context of presumption, according to Damon (2002), children are demanded to prepare both to learn from their social settings and to follow their own consciences when the need arises. He further states that educators should understand that teaching morality means teaching as well as helping students to behave personal moral identity. The teaching is very important because morality is a common value that will bring and form the child's moral sense in any situation

On the other hand, Kertajaya (2011), quoting Josephson Institute of Ethics, states that at least there are six pillars of character which should be taken into account in the teaching of morality. They are trustworthiness, respect, fairness, citizenship, caring and responsibility. These pillars are well known as common value which every nation cares and developsin their transactional activity and communication to maintain their life.

The first pillar, trustworthiness is believed to be the basic element of human character, and is reflected in honesty and integrity. While respect, the second pillar, is an attitude which performs the capacity and quality of how people care others and understand differences respectfully. Therefore, respectful people will 
always show their tolerance and deal with building understanding for others properly.

The third pillar,fairness, according to Pines (2006), is an attitude which enables people to weigh the public goods against the individual goods. In other words, being fair means being able to look at what is right above what a person wants, putting aside the things he/shebelieves in. The result is then caring people is the ones who always try to understand others, whatever and whoever the others are.

The fourth pillar, citizenship, is known as capacity of feeling and thinking to support what is best for the larger Group (Pines, 2006). He adds that when one follows the rules made by society and ready to fight to change unjust law or intolerant views, he /she is a good citizen.

The fourth pillar, caring is the act of being concerned about or interested in another person or situation. Mcelmeel (2002) thinks that caring is feeling or acting with compassion, concern, or empathy. Caring people are known as someone who are ready to help someone else who needs him and are also ready to sorrow for others.

The fifth pillar, responsibility, proposed by Kertajaya (2011) as refers to the meaning that we must do what we ought to do, and the responsibility on whatever we do. This pillaris also defined by Nucci (2001) as a term which deals with sociological domain. It means that the social value of doing something in a certain social setting should be considered by the doer of a certain act.

The question is how to bring and integrate the norm/ attitude/ character into the classroom of English teaching and learning process. If this can be done, the further question is what kinds of norms selected by the textbook writer. It has been understood that a textbook, as stated by Buckingham in Tarigan (1993) is a simply learning material commonly used at schools and universities to support the teaching and learning process.

Garinger (2002) adds that a textbook can serve different purposes for teachers: as a core resource, as a source of supplemental materials, an inspiration for classroom activities, even as curriculum itself. The English teachers can use textbook as the main or additional source of teaching. Therefore Fauziati (2010) suggests that to meet the needs, the textbook must not contain language skills demanded by the curriculum but also the needs of the students. Within this point, it is clear that the mission to teach and to bring characters or norms into the classroom can be done by utilizing textbook.

Investigating the shared characters or norms in a text can be done by applying Fairclough (1992) procedures in critical discourse analysis. The procedures are started by describing the formal properties of the text, followed by interpreting the text and ended with explaining the interaction and the social context.

In the Description step, the formal discourse choices of the text are analyzed to reveal the lexical and structural trends in the text. Fairclough (1992) stated that this analysis concerns three sections: 1) vocabulary, 2) grammar, and 3) textual structures. 
In interpreting the text, the important thing to do is analyzing the situational context and intertextual context (Fairclough, 1992). He adds that situational context can be traced within the features of the physical situation and properties of participants, while intertextual context is a matter of deciding which series of a text belongs to.

\section{METHOD}

The design of the research was descriptive qualitative which aimed at investigating the realization of norms in the reading passages of Senior High School English textbook. The data of this research was norms, while the data sourceswere reading passages in the English textbook.

Data collection was done by selecting the textbook which resulted on choosing the one that is published by The Indonesian Ministry of Education and Culture. There are 20 (twenty) reading passages in the textbook which were investigated in this research. All reading passages were read thoroughly in order to select which of them have the content of norm, confirming with the six basic pillars of character or norm which are proposed by Kertajaya (2011). After the confirmation, there were only 8 (eight) out of 20 (twenty) texts which share the basic pillars of character or norm.

The data were analyzed by first, searching words, phrases or utterances which significantly correlate with the six basic pillars of character or norm. This step was done in order to help the description and interpretation of the text. Second, analyzing situational and intertextual context to answer several questions proposed by Fairclough (1992): 1) What's going on? (activity, topic, purpose, 2) Who's involved? (subjects position), 3) In what relations? (what relationship of power, social distance), 4) What's the role of language? (channels).

Third, describing and interpreting the norms or characters in the reading passages of the English textbook 2015 developed by The Ministry of Education and Culture.These were done by applying Fairclough (1992) proposal, that was by analyzing the formal discourse choices and analyzing the situational context and intertextual context.

\section{RESULTS AND DISCUSSION}

The result of the analysis shows that not all pillars of norm are shared in each text. The sharing norm was greatly depended on the topic and the purpose of the text, the position and relationship of power between people that are mentioned in the text.

The norm of trust is shared through the first text. This text, entitled Six Things To Do If You Visit Seattle, is a kind of procedure text which is combined with some description about the ferry and the destination. It promotes six experiences that the readers must have if they visit Seatle where city and nature come together. The writer even asks the readers to have this list of six experiences in order to have unforgettable sights and sounds.

In this kind of text, the writer of the text seems to have a bigger power than the readers as the writer knows everything about what is described and discussed. 
With this kind of power relationship, he/she tried to build trust of the reader with the purpose that the information and the manual procedure or the instruction can be understood and followed by the readers.

The need for building trust can be read from the utterances like Feel the fresh air on your face as you sail to Brainbrige Islandon a Washington State Ferry, Book a night at one of the many cozy B and Bs or resorts available throughout the Sun Juan Islands, See exciting and experimental works at Chihuly Garden and Glass, and Explore the space needle and Pacific science Center. Those utterances are something like to reinforce the readers to follow "the instruction" and to do those instructions enjoyably and safely. In other words, the writer tries a big effort to build trust of the readers on the thing being discussed.

Discipline is the next norm being shared in this textbook, especially in the second and eighth text. The second text is as a matter of fact a transcript of a dialog between three students who are preparing their school project. All participants contribute the talk fairly, promoting, asking and suggesting themselves to do and to have something the best they can afford. This dialog shows equivalent power relationship, meaning that no one has a need to maintain the power during the talk. Therefore, each of them has the same position to share everything. This position is shown by the choice of expression which represents invitation and suggestion. In this text, the shared norm is being discipline.

The invitation or suggestion can be identified from the use of I think, Let's, I reckon, I'd say, and it should or we should. Those expressions can be found in the utterances like Hey, guys, I think we should finish our Biology assignment before Sunday, Let's have a look at some references from the internet, I reckon we have to think of an underwater animal and make a poster about it, I'd say we should make a poster about giant squid. Those utterances perform invitation to work on the right track and to be discipline in finishing the assignment.

The norm of discipline is also shown in the eighth text. This text is discussing regulations of living in an apartment. The discussion on the text begins with a new way of life in Jakarta, that is living in an apartment. Everybody who chooses to live in an apartment should study all the relevant regulations in order to guarantee his or her own security.

This norm is therefore shared in this text and can be traced from the utterances of Tenants must obey certain regulations when living in an apartment, which is far different from living in a landed-house, Tenants of an apartment should abide by regulations set by the owner of the high-rise building, an owner of apartment should also consider aspects fo design and building materials that are safe for children, children's safety should be in the main concern with regards to the building materials that are used.

Respect to others is the norm which is shared in three reading passages. Thisnorm is identified in text 3 (three), 6 (six) and 7 (seven). The third text is a transcript of a dialog between Armida, Diana, Zahra and Raisa. They talk about birthday party for Armida's grandmother and about the accreditation of their school. They share the norm of respect to others by exclaiming Wow ! That sounds great. How old is she?, and Wow! That's terrific. These expressions are 
kinds of scaffolding talks which can be adapted by students when theywant to show their respect to others.

The sixth text is discussing about best friend. A best friend may become a true friend if he or she meets several characteristics. One of them is respect to others because respect to others will perform healthy relationship. In this text, the norm of respect to others are realized through the utterances like True friends respect their friends' life principle, and will not ask them to place the friendship before the principle, They will not ask their friends to compromise the principle in the name of friendship or anything else.

The seventh text was also used by the writer to share respect to others. This text is discussing about a traditional community which decided to turn its back away from modern technology, Baduy people. The text tries to describe not only the community which can be grouped into two communities, but also the culture which is highly correlated with their unique way of life. However, Baduy life is its own choice and everybody should respect to its choice and way of life.

The norm respect to others are shared by using these expressions: it is prohibited to take photographs, if we're thinking about what to do when we come here, then we need not to worry because there are lots on offer, it is a very relaxing experience and sometimes visitors find themselves missing the simplicity and beauty of the place.

The norm of being self confidence is shared through the fourth text.This text is a kind of application letter for certain vacancy which is completed with full description of the writer's capacity and experience to ensure the manager to hire her.The writer has successfully shown a good example of writing a good application letter and of a good personality of one who writes this letter.

In this text, the writer uses the expressions like As you can see from my enclosed resume, my experience and qualifications match this position requirements, My current position managing the local branch of a national shoe retailer, has provided the opportunity to work under a high pressure, and I look forward to the opportunity to personally discuss why I am particularly suited this position. The choice of words used in those utterances clearly shows the norm being shared in the text.

\section{CONCLUSION}

It is really interesting to conclude here that the writer of the textbook care the norms or characters which should be educated to the young generation. The choice to share the norms or character is in line with the policy of the government who seriously build the students capacity, not only on the development of their knowledge, but also on their attitude and character. Building attitude can successfully be done by sharing norms which as a matter of fact is the valuable asset of the nation. In teaching and learning process, the use of textbook in Indonesian classroom is still very significant. Therefore, the finding of this research which shows the contribution of the writer in sharing the basic pillars of norm, is also a valuable finding which may be useful for developing the teaching and learning process. 


\section{REFERENCE}

Damon, William. 2002. Bringing in a New Era in Character Education. California: Hoover Institute Press.

Fairclough, N. 1992. Language and Power. Longman

Fauziati, Endang. 2010. Teaching English as a Foreign Language (TEFL). Surakarta: PT Era Pustaka.

Garinger, D. (2002). Textbook Selectiom for the ESL Classroom. Eric Clearinghouse on Languages and Linguistics.

Harmer, Jeremy. 2007. The Practice of English Language Teaching. PearsonLongman.

Hughes, R. (2002). “Teaching and Researching Speaking”. Harlow: Pearson Education Limited.

KementrianPendidikandanKebudayaan. (2014). English Textbook. Jakarta: KementrianPendidikandanKebudayaan.

Kertajaya, H. 2011. Grow with Character. Gramedia.

Mcelmeel, S., L. 2002. Character Education. A Book Guide for Teachers, Librarians and Parents. Colorado: A division of Publishing Group. Inc.

Nucci. Larry P. 2001. Education in the Moral Domain. Cambridge: Cambridge University Press

Pines, Susan. 2006. Young Person's Character Education Handbook. Jist Publishing Inc.

Tarigan, Henry G and TariganDjago.1986. Telaah Buku Teks Bahasa Indonesia. Bandung: PT. Angkara.http://en.m.wikipedia.org/wiki/Wikipedia: ManualofStyle/Captions.

Wu, Vivian Wen-Chi, and Pen- hsiang Natalie Wu. 2008. Creating and Authentic EFL Learning Environment to Enhance Student Motivation to Study English.

Asean EFL Journal Volume 10. Issue 4 Article 11. (http://www.asian-efljournal.com/December_08_wcw.php, accessed July 7, 2010). 